\title{
Task 1.15 - Enhanced Bioremediation of Coal Tar- Contaminated Soil
}

\author{
Semi-Annual Report \\ July 1 - December 31, 1997 \\ PECEIVED \\ Nov 231998 \\ OSTI \\ By: \\ John R. Gallagher
}

Work Performed Under Contract No.: DE-FC21-93MC30097

For

U.S. Department of Energy

Office of Fossil Energy

Federal Energy Technology Center

P.O. Box 880

Morgantown, West Virginia 26507-0880

By

Energy \& Environmental Research Center

University of North Dakota

P. O. Box 9018

Grand Forks, North Dakota 58202-9018 


\section{DISCLAIMER}

This report was prepared as an account of work sponsored by an agency of the United States Government. Neither the United States Government, nor any agency thereof, nor any of their employees makes any warranty, express or implied, or assumes any legal liability or responsibility for the accuracy, completeness, or usefulness of any information, apparatus, product, or process disclosed or represents that its use would not infringe privately owned rights. Reference herein to any specific commercial product, process, or service by trade name, trademark, manufacturer, or otherwise does not necessarily constitute or imply its endorsement, recommendation, or favoring by the United States Government or any agency thereof. The views and opinions of authors expressed herein do not necessarily state or reflect those of the United States Government or any agency thereof.

Available to the public from the National Technical Information Service, U.S. Department of Commerce, 5285 Port Royal Road, Springfield, VA 22161; phone orders accepted at (703) 487-4650.

\section{ACKNOWLEDGMENT}

This semiannual was prepared with the support of the U.S. Department of Energy (DOE) Federal Energy Technology Center Cooperative Agreement No. DE-FC21-93MC30097. However, any opinions, findings, conclusions, or recommendations expressed herein are those of the author(s) and do not necessarily reflect the views of the DOE.

\section{EERC DISCLAIMER}

LEGAL NOTICE This research report was prepared by the Energy \& Environmental Research Center (EERC), an agency of the University of North Dakota, as an account of work sponsored by U.S. Department of Energy. Because of the research nature of the work performed, neither the EERC nor any of its employees makes any warranty, express or implied, or assumes any legal liability or responsibility for the accuracy, completeness, or usefulness of any information, apparatus, product, or process disclosed, or represents that its use would not infringe privately owned rights. Reference herein to any specific commercial product, process, or service by trade name, trademark, manufacturer, or otherwise does not necessarily constitute or imply its endorsement or recommendation by the EERC. 


\section{DISCLAIMER}

Portions of this document may be illegible in electronic image products. Images are produced from the best available original document. 


\section{TABLE OF CONTENTS}

LIST OF FIGURES $\ldots \ldots \ldots \ldots \ldots \ldots \ldots \ldots \ldots \ldots \ldots \ldots \ldots \ldots \ldots \ldots \ldots \ldots \ldots \ldots \ldots$

LIST OF TABLES $\ldots \ldots \ldots \ldots \ldots \ldots \ldots \ldots \ldots \ldots \ldots \ldots \ldots \ldots \ldots \ldots \ldots \ldots \ldots \ldots \ldots \ldots$

1.0 BACKGROUND $\ldots \ldots \ldots \ldots \ldots \ldots \ldots \ldots \ldots \ldots \ldots \ldots \ldots \ldots \ldots \ldots \ldots \ldots \ldots \ldots \ldots$

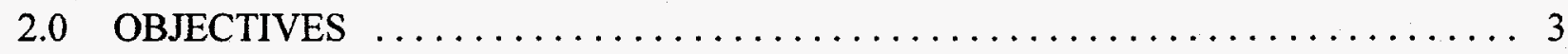

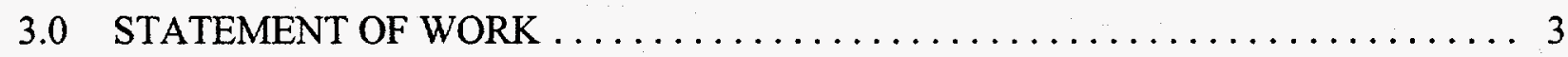

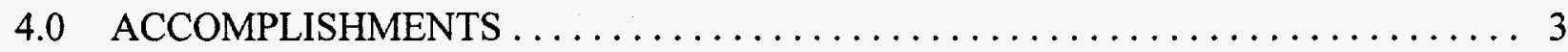

\section{LIST OF FIGURES}

1 Total PAHs vs. time for three phases of the biodegradation process $\ldots \ldots \ldots \ldots \ldots 2$

\section{LIST OF TABLES}

1 Analysis of PAHs in MGP Soil from Des Moines, Iowa $\ldots \ldots \ldots \ldots \ldots \ldots \ldots$ 


\section{TASK 1.15 - ENHANCED BIOREMEDIATION OF COAL TAR-CONTAMINATED SOIL}

\subsection{BACKGROUND}

The remediation of sites where soils have been contaminated with hydrophobic organic compounds is a major problem. This is especially true for manufactured gas plants (MGP) and similar industries. Gasification of fossil fuels has resulted in the production of tars that contain polyaromatic hydrocarbons (PAHs). PAHs are of concern because they are persistent in the environment and because many of them are carcinogenic. When soils contain very high concentrations of PAHs and other tar components, it is generally most feasible to use a chemical-physical remediation technique such as incineration. However, when the contaminant concentrations are medium to low, the most inexpensive technology is generally biological treatment. Biological treatment is an environmentally acceptable method of remediation that is relatively low-cost for many organic contaminants. PAHs and similar hydrophobic compounds, however, present major challenges to the microbial methods. These problems can be broken down into two related areas: mass transfer and bioavailability.

The water solubility of most PAHs is very small, and they have very low vapor pressures. As a result, the diffusion of the sorbed PAHs to a location where a biodegrading microorganism can encounter it is often limiting. Complicating this is that especially in aged samples, the PAHs are bound so strongly to soil components, they are not available for the microorganisms. These two phenomena can be better understood by examination of a typical biodegradation curve, such as might be observed for mixed PAHs. In Figure 1, there are three phases of the biodegradation process plotted with respect to time. In the first phase, concentrations are changing only slowly as the microbes adapt to the conditions, grow to a larger population, and begin to biodegrade the PAHs. The second phase is the phase of rapid, often logarithmic, biodegradation. The third and last phase is that period when available concentrations of PAHs are dropping so that the microorganisms cannot degrade them. The rate observed during the second phase is dependent on the size of the microbial population that can degrade the contaminants, the availability of the contaminants, and suitable nutrients (e.g., phosphorus) and electron acceptors (e.g., oxygen). When readily biodegradable contaminants are present, this phase is often very rapid. However, when any one of the above factors is limiting, a reduced rate is observed.

Studies where conditions have been optimized for mass transfer of hydrophobic compounds, such as by rapid mixing or by the addition of surfactant, have shown that these rates are generally much lower than would be possible with higher mass transfer rates (mass transfer limited). Techniques to improve mass transfer would allow this phase to end more quickly, resulting in reduced costs. In the third phase, the availability of contaminants has dropped to near zero, and even with prolonged incubation, concentrations will not drop significantly. If the lower limit achievable in a particular soil is above the regulatory limit, the biological technology will not be suitable, and a more expensive and disruptive technique (e.g., incineration) must be considered. 


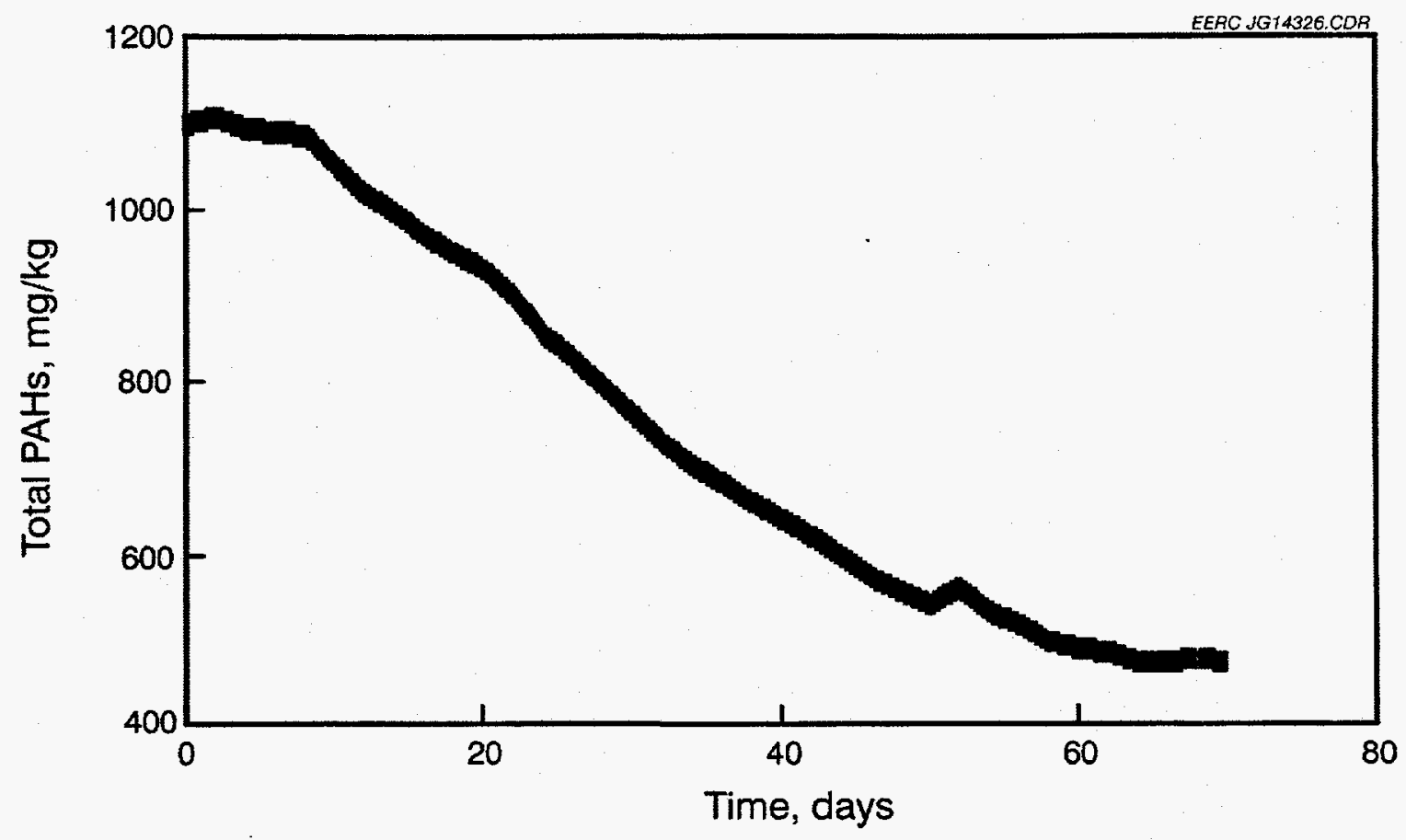

Figure 1. Total PAHs vs. time for three phases of the biodegradation process.

Studies have shown that the concentration of contaminants in that third phase is on the soil and is removable by strong solvents. In fact, these contaminants can be removed by a strong solvent, and when these contaminants are added back to a soil containing a suitable biodegrading microbial population, they will be rapidly and nearly completely degraded. This indicates that although the strong solvent can solubilize the contaminants, the microbes are not able to encounter them. Other investigators have suggested that the contaminants are present in a physical or kinetic trap within the soil matrix. Gas Research Institute has been active in a program to investigate these bioavailability phenomena because of the great impact they have on these and related industries.

Techniques are needed to mobilize contaminants to improve their availability for biodegradation to lower the achievable remediation end point (Phase 3) and to improve mass transfer so that remediation goals can be achieved more quickly (Phase 2). One technique that has potential for both of these problems is through the use of acoustic energy. The addition of energy is apparently necessary to overcome the binding energy of the contaminants and mobilize them. Acoustic energy has a history of use in the laboratory and in industry to make emulsions and solutions and to remove scale and fouling, among others. Weiss Associates of Emeryville, California, has conducted tests using lower-frequency acoustics to mobilize nonaqueous-phase liquids with good success. The use of lower frequency is important because although ultrasound is more energetic, it is also dampened quickly in soils, greatly reducing the radius of influence and applicability. Lower-frequency acoustics have the potential to supply the required energy in a more cost-effective manner. In addition, research by Weiss Associates has shown that it is possible to steer the beam of sonic energy to the zones that contain the most contamination. 


\subsection{OBJECTIVES}

The objective is to determine the ability of acoustic energy to improve bioavailability or improve mass transfer of PAHs from soil to water phases where microorganisms can access them.

\subsection{STATEMENT OF WORK}

A sample of soil will be collected that is contaminated with PAHs and has been exposed to the PAHs for a relatively long period of time (aged). The soil will be homogenized and distributed into borosilicate serum vials. The aliquots of soil will be slurried with an aqueous nutrient solution, oxygen will be added to the headspace, and the vial will be sealed with a Teflon-faced silicone stopper. Replicate vials will be exposed to acoustic energy using a benchscale laboratory unit supplied by Weiss Associates. At time intervals, replicate vials will be extracted with solvent and analyzed by gas chromatography to determine the quantity of PAHs remaining. Some replicates will be treated to kill the microorganisms in the soil by autoclaving or chemical sterilization. These killed vials will be controls for abiotic loss of PAHs. The effect of acoustics on PAH biodegradation kinetics can be determined from a comparison of the loss of PAHs between untreated and acoustically treated samples.

\subsection{ACCOMPLISHMENTS}

Progress on this project has been delayed somewhat because of difficulties in obtaining and operating the acoustic unit. This unit was received at the Energy \& Environmental Research Center (EERC) earlier; however, the datalogging software and associated hardware was not functional. The data-logging system has just recently been put on-line, and work on this project will be completed in the coming quarter.

In order to properly demonstrate the ability of acoustic energy to increase bioavailability, an aged, PAH-contaminated soil from a MGP site is desired. This soil was obtained from a Des Moines, Iowa, site. Samples of this soil will be the subject of another project that will analyze the soil to determine the difficulty of extraction, which is taken as a measure of how tightly the contaminants are bound. These data are expected to complement this project.

An analysis supplied with the soil shows that it has an aliphatic content of about $1500 \mu \mathrm{g} / \mathrm{g}$ and an aromatic content of about $9000 \mu \mathrm{g} / \mathrm{g}$. A breakdown of the key components is shown in Table 1. 


\section{TABLE 1}

Analysis of PAHs in MGP Soil from Des Moines, Iowa Compound $\mathrm{ng} / \mathrm{g}$

Naphthalene 310,000

C1-4 Naphthalenes

798,000

Acenaphthylene

120,000

Biphenyl

39,000

Fluorene

100,000

C1-3 Fluorenes

87,000

Anthracene

78,000

Phenanthrene

280,000

C1-4 Phenanthrenes/Anthrenes

447,000

Dibenzothiophene

44,000

C1-3 Dibenzothiophenes

110,000

Fluoranthene

85,000

Pyrene

140,000

C1-3 Fluoranthenes/Pyrenes

249,000

Benzo[ $a]$ anthracene

51,000

Chrysene

45,000

C1-4 Chrysenes

97,300

Benzo[ $[b-k]$ fluoranthene

53,000

Benzo[a-e]pyrene

75,000

Perlyene

8,000 